\title{
Comparative Study of Morphological Characteristics and Body Composition between Different Team Players from Serbian Junior National League: Soccer, Handball, Basketball and Volleyball
}

\author{
Estudio Comparativo de las Características Morfológicas y Composición Corporal entre Diferentes \\ Jugadores de Equipos de la Liga Nacional Junior de Serbia: Fútbol, Balonmano, Baloncesto y Voleibol
}

\author{
Bojan Masanovic
}

MASANOVIC, B. Comparative study of morphological characteristics and body composition between different team players from Serbian junior national league: soccer, handball, basketball and volleyball. Int. J. Morphol., 37(2):612-619, 2019.

SUMMARY: The purpose of this study is to define every subsample with precision, to give an overview of the importance of the differences between different team players, as well as to point to the closeness along with the remoteness between them, and finally, to determine latent anthropologic characteristics which, when in interaction, contribute to significant differences and better comprehension of the specifics of every mentioned sport. Sixty-seven males were enrolled in the study, divided into four groups: twenty-five soccer players, fifteen handball players, thirteen basketball players and fourteen volleyball players. All subjects were assessed for the anthropometric measures required for the calculation of body composition variables, using the standardized procedures recommended by the established literature. Data was analysed using SPSS and the descriptive statistics were expressed as a mean (SD) for each variable, while the ANOVA and LSD Post Hoc tests were carried out to detect the effects of each type of sport, distinct features that have been identified by calculating the discrimination coefficient have determined the specifics of the subsamples, and their grouping was demonstrated by calculating Mahalanobis distance. The results showed that a significant difference was found for body height, body weight, muscle contents of body, fat contents of body, residue mass, ideal body mass and lean body mass. There is no significant difference in the body mass index and bone contents of body. It was confirmed that there is a clearly defined line between the players in different sports and it is possible to determine the characteristics of players of each sport. The results also indicate that the least amount of differences appears between volleyball and basketball, and that the sports that are most apart are volleyball and handball. Therefore, these findings may give coaches from the region a more precise top soccer, handball, basketball and volleyball player profile, and suggest them to follow recent selection process methods and be more careful during talent identification.

KEY WORDS: Morphological Characteristics; Body Composition; Different Sports; Junior.

\section{INTRODUCTION}

Research of anthropometric characteristics among athletes of different sports suggests that athletes of different sports have their own specific characteristics (Singh et al., 2010). The athlete's affiliation to a certain sport implies his "biotype", which gives him the advantage of playing one sport and not the others (Masanovic, 2008; Krzykaa \& Leszczynski, 2015).

Considering that a large number of athletes of almost equal quality are involved in the biggest sporting events, it will be seen that the nuances make the difference between the quintessential and those who win (Vukasevic et al., 2018). That is why it is very important to answer the question of what qualities and abilities athletes need to possess in order to achieve top results. When we get the answer to that question, we move on to the next task, which is finding and selecting young athletes with such predispositions.

In some sports disciplines (e.g. basketball), a large body height, along with other necessary features, will give one a significant advantage in achieving success in that discipline (Popovic et al., 2014). The same way, one who has less body weight, who is short or with average height, will have the advantage in achieving more success in doing long runs over those who have more body weight (Jeukendrup \& Gleeson, 2009). 
Body composition can affect strength and agility (Massuça \& Fragoso, 2011), whereas body mass can influence an athlete's speed, endurance, and power. It is well known that excessive fat mass compromises the physical performance (Strel, 2006; Nikolaidis \& Vassilios-Karydis, 2011), acts as a dead body mass in activities where the body must be repeatedly lifted during locomotion and jumping, decreasing performance and increasing energy demands (Ramos-Campo et al., 2014). On the contrary, muscleskeletal mass is an indicator of sports performance, because it contributes to the energy production during high-intensity activities and provides absolute strength to athletes (Vila Suárez et al., 2008).

However, one should not lose sight of the fact that the significance of morphology and body composition is only relative, and that putting in a high level performance is the result of a complex of different factors (Rexhepi \& Brestovci, 2010; Popovic et al., 2013). This thesis is also proven by recorders in some disciplines that are not fully in line with the ideal profile of that certain discipline.

Many previous studies have evaluated ideal anthropometric profiles of soccer, handball, basketball and volleyball players and they have precisely described the biotype of each of the mentioned sports (Popovic et al., 2013; Toselli et al., 2014; Barraza et al., 2015; Rivera-Sosa, 2016; Fieseler et al., 2017; Sporis et al., 2017; Bankovic et al., 2018). However, they have not provided an insight into the similarities, differences and distances between certain parameters. Hence, the purpose of this study is to define every subsample with great precision, to give an overview of the importance of the differences between different team players, as well as to point to the closeness along with the remoteness between them, and finally, to determine latent anthropologic characteristics which, when in interaction, contribute to significant differences and better comprehension of the specifics of every mentioned sport.

\section{MATERIAL AND METHOD}

A cross-sectional data were collected from sixtyseven young sportsmen. They were divided into four groups: twenty-five soccer players ( $16.64 \pm 0.49$ years.) from the junior premier league in Serbia, fifteen handball players ( $16.93 \pm 0.59$ years.) from the junior premier league in Serbia, thirteen basketball players (17.08 \pm 0.28 years.) from the junior premier league in Serbia and fourteen volleyball players (17.36 \pm 0.74 years.) from the junior premier league in Serbia. The measurements were carried out in winter preparation period. Criteria for selection of subjects for the sample were as follows: that they have been a part of the first team at the club for at least one year and that they are in good health.

All subjects gave their written consent and the local ethics committee approved the protocol of the study. All subjects were assessed for the anthropometric measures required for the calculation of body composition variables, using the standardized procedure recommended by the International Biological Program (IBP) standards respecting the basic rules and principles related to the parameter choice, standard conditions and measurement techniques, as well as the standard measuring instruments adjusted before measurement was carried out. Height and weight were measured in the laboratory with the subject dressed in light clothing. Height was measured to the nearest $0.1 \mathrm{~cm}$ using a fixed stadiometer, and weight was measured to the nearest $0.1 \mathrm{~kg}$ with a standard scale utilizing a portable balance. Body mass index (BMI) was calculated as body mass in kilograms divided by height in meters squared $\left(\mathrm{kg} / \mathrm{m}^{2}\right)$. Skinfolds $(\mathrm{mm})$ were measured at six sites: triceps skinfold thickness, forearm skinfold thickness, thigh skinfold thickness, calf skinfold thickness, chest skinfold thickness and abdominal skinfold thickness (using a skinfold caliper). Each individual measurement and the sum of the six measurements were used for analysis. The circumferences of the upper and lower arm and the upper and lower leg were measured in centimeters and the following diameters were measured to the nearest $0.1 \mathrm{~cm}$ : elbow diameter, wrist diameter, diameter of the knee, diameter of the ankle. To reduce measurement variation, the same investigator examined all of the subjects. The values of bone, muscular, and fat contents of body composition were acquired by distributing all the measured variables in formulas by Matiegka (1921). Ideal body mass was calculated by Demole's formula, based on body height and age, while lean body mass was calculated by Willower's formula which requires body mass and skinfold thickness (Jakonic, 1993; Masanovic, 2008).

The data obtained in the research was processed using the application statistics program SPSS 20.0, adjusted for use on personal computers. The descriptive statistics were expressed as a mean (SD) for each variable. Analysis of the variance (ANOVA) and the LSD Post Hoc test were carried out to detect the effects for each type of sport (soccer or volleyball) on each variable: body height, body weight, body mass index (BMI), muscle, bone and fat content of the body, as well as ideal body mass (IBM) and lean body mass (LBM). Distinct features that have been identified by calculating the discrimination coefficient (Discriminant Analysis) have determined the specifics of the subsamples, and their grouping was obtained by calculating Mahalanobis distance. The significance was set at an alpha level of 0.01 . 


\section{RESULTS}

The anthropometric characteristics and body composition of subjects are shown in Table I. By examining the displayed variables of the soccer players, the lowest body weight and body fat content, as well as matching values of body weight and ideal body mass can be observed, and this indicates that this group of players is undergoing a very intense training process. As for handball players, the greatest inconsistency of the standard deviation is observed, which can lead to the conclusion that this pattern is the least homogeneous in comparison with the others. Based on this it can be concluded that the difference between players who play different positions is higher in handball than in other sports. It is also noted that handball players have somewhat greater body weight than ideal body mass, slightly higher value of the muscle content of the body and the highest value of the fat content. Based on these data, it can be concluded that success comes with great benefit of body weight, absolute strength and force, and that the training process of this group of sportsmen is lower than in other measured groups. Basketball players have high body height values, and body weight values are consistent with ideal body mass values. The highest values in relation to others are observed in the muscle content of the body, but very low values can be seen in the fat content. The conclusion is that morphological characteristics and body composition in this sport are very important for achieving success, and that the training process must be of high intensity, which also points to the complexity of this sport. Finally, an overview of the measured and calculated variables in volleyball players shows the highest values of body height and body weight. The body mass coincides with the ideal body mass, and the values of the fat content are very low. It is concluded that the morphological characteristics and body composition are of great importance for success in this sport, and that good selection is very important.
By reviewing Table II which shows the results of multivariate analysis, it is clear that in the whole system of the compared parameters, there is a statistically significant difference between morphological characteristics and body composition between different sports players $(\mathrm{p}=.000)$.

Table II. Significance of differences in anthropometric status and body composition of different sports players.

\begin{tabular}{cccc}
\hline & $\mathrm{n}$ & $\mathrm{F}$ & $\mathrm{p}$ \\
\hline Manova & 10 & 6.65 & .000 \\
\hline
\end{tabular}

Table III shows the results of the univariate analysis, it is clear that there were statistically significant differences in seven out of the nine variables among the players of different sports. Hence, a significant difference was found for body height $(\mathrm{F}=33.338)$, body weight $(\mathrm{F}=17.995)$, muscle contents of body fat $(\mathrm{F}=11.812)$, fat contents of body fat $(\mathrm{F}=11.941)$, residue mass $(\mathrm{F}=11.858), \mathrm{IBM}(\mathrm{F}=30.707)$ and LBM $(\mathrm{F}=18.192)$. There is no significant difference in the body mass index $(\mathrm{F}=2.094)$ and bone contents of body fat $(\mathrm{F}=2.838)$.

Table III. The significance of the difference between different sports players for each anthropological characteristic (anthropometric status, body composition, derived indexes)

\begin{tabular}{lcc}
\hline ANOVA & $\mathrm{f}$ & $\mathrm{P}$ \\
\hline Height $(\mathrm{cm})$ & 33.338 & .000 \\
Weight $(\mathrm{kg})$ & 17.995 & .000 \\
Body mass index $\left(\mathrm{kg} / \mathrm{m} \_\right)$ & 2.094 & .110 \\
Muscle content of body $(\%)$ & 11.812 & .000 \\
Bone content of body $(\%)$ & 2.838 & .045 \\
Fat content of body $(\%)$ & 11.941 & .000 \\
Residue mass $(\%)$ & 11.858 & .000 \\
Ideal body mass $(\mathrm{kg})$ & 30.707 & .000 \\
Lean body mass $(\mathrm{kg})$ & 18.192 & .000 \\
\hline
\end{tabular}

Table I. Descriptive data of 67 males enrolled in the study.

\begin{tabular}{lcccc}
\hline \multirow{2}{*}{ Variables } & Socer $(\mathrm{n}=25)$ & Handball $(\mathrm{n}=15)$ & $\begin{array}{c}\text { Basketball } \\
(\mathrm{n}=13)\end{array}$ & $\begin{array}{l}\text { Volleyball } \\
(\mathrm{n}=14)\end{array}$ \\
\cline { 2 - 5 } & \multicolumn{4}{c}{ Mean \pm Standard Deviation } \\
\hline Height $(\mathrm{cm})$ & $177.81 \pm 6.63$ & $181.51 \pm 5.33$ & $193.60 \pm 7.70$ & $194.28 \pm 5.30$ \\
Weight $(\mathrm{kg})$ & $69.90 \pm 6.78$ & $74.73 \pm 10.17$ & $80.00 \pm 9.76$ & $82.04 \pm 8.85$ \\
Body mass index $(\mathrm{kg} / \mathrm{m})$ & $22.10 \pm 1.74$ & $22.66 \pm 2.83$ & $21.32 \pm 1.99$ & $21.71 \pm 1.81$ \\
Muscle content of body (\%) & $47.94 \pm 2.12$ & $48.85 \pm 4.03$ & $49.81 \pm 2.58$ & $48.16 \pm 2.20$ \\
Bone content of body (\%) & $16.76 \pm 1.48$ & $17.03 \pm 2.49$ & $16.95 \pm 1.15$ & $16.52 \pm 1.20$ \\
Fat content of body (\%) & $12.12 \pm 2.78$ & $16.39 \pm 3.28$ & $12.48 \pm 3.67$ & $13.33 \pm 1.93$ \\
Residue mass $(\%)$ & $23.14 \pm 3.52$ & $17.74 \pm 3.88$ & $20.75 \pm 2.31$ & $21.96 \pm 1.81$ \\
Ideal body mass (kg) & $70.00 \pm 4.99$ & $72.88 \pm 4.01$ & $81.97 \pm 5.82$ & $82.64 \pm 4.11$ \\
Lean body mass $(\mathrm{kg})$ & $63.18 \pm 4.98$ & $65.97 \pm 6.92$ & $70.87 \pm 6.63$ & $72.21 \pm 6.65$ \\
\hline
\end{tabular}


Table IV. Characteristics of different sports players

\begin{tabular}{lccccc}
\hline Sports & C. Disc & Soccer & Handball & Basketball & Volleyball \\
\hline Height & 1.039 & $175.07 ; 180.55$ & $178.56 ; 184.47$ & $188.95 ; 198.25$ & $191.22 ; 197.34$ \\
Bone content of body & .063 & $16.15 ; 17.38$ & $15.66 ; 18.41$ & $16.26 ; 17.65$ & $15.83 ; 17.21$ \\
Fat content of body & .062 & $10.97 ; 13.27$ & $14.57 ; 18.20$ & $10.27 ; 14.70$ & $12.22 ; 14.44$ \\
Muscle content of body & .057 & $47.07 ; 48.82$ & $46.61 ; 51.08$ & $48.25 ; 51.37$ & $46.89 ; 49.43$ \\
Residue mass & .055 & $21.69 ; 24.60$ & $15.59 ; 19.89$ & $19.36 ; 22.5$ & $20.61 ; 23.32$ \\
Weight & .016 & $67.10 ; 72.70$ & $69.10 ; 80.37$ & $74.10 ; 85.90$ & $76.93 ; 87.14$ \\
\hline
\end{tabular}

By examining Table IV in the order of the degree of discrimination, with the coefficient of discrimination, the characteristics of each group of sportsmen can be logically derived, starting with the highest difference: body height 1.039 , bone content of the body 0.063 , fat content of body 0.062 , muscle content of body 0.057 , residue mass 0.055 , body weight 0.016

The characteristic of soccer players is statistically significantly lower body height (177.81) and body weight (69.90) in comparison with basketball and volleyball players, while the characteristic of handball players is statistically significantly lower body height (181.50) in comparison with basketball and volleyball players. Conversely, basketball and volleyball players are characterized by statistically significantly higher value of body height $(193.60 ; 194.28)$, in comparison with soccer and handball players. Based on the fact that $\mathrm{p}=.000$ (of discriminative analysis) it has been confirmed that there is a clear line between sportsmen who play different sports which makes it possible to determine their characteristics in the broader sense, in relation with the anthropometric status and body composition.

Calculation of Mahalanobis distance (Table V) of members of different sports gives another indication of similarity or difference. The results from the table indicate that the least distance appears between volleyball and basketball (.81) and the farthest sports are volleyball and handball (2.94).

Table V. Mahalanobis' distance of anthropometric status and body composition between players of different sports.

\begin{tabular}{lrrrr}
\hline & \multicolumn{1}{c}{ Soccer } & Handball & Basketball & Volleyball \\
\hline Soccer & .00 & 1.91 & 2.67 & 2.67 \\
Handball & 1.91 & .00 & 2.81 & 2.94 \\
Basketball & 2.67 & 2.81 & .00 & .81 \\
Volleyball & 2.67 & 2.94 & .81 & .00 \\
\hline
\end{tabular}

The grouping of anthropometric status and body composition of athletes is shown in Table VI and Figure 1.

Based on the dendrogram (Fig. 1), it is clear that the closest sports are basketball and volleyball, at distance of
Table VI. The grouping of anthropometric status and body composition

\begin{tabular}{llr}
\hline Level & Closest & Distance \\
\hline Basketball & Volleyball & 0.81 \\
Soccer & Handball & 1.91 \\
Soccer & Basketball & 3.77 \\
\hline
\end{tabular}

.81 , and the biggest difference is between soccer and basketball, the distance of 3.77 .

The charts $(2,3,4)$ show the position and characteristics of anthropometric status and body composition of members of different sports in relation to the 3 most discriminative parameters. Based on the graphical review of ellipses (confidence intervals) it is possible to gain insight into respective positions and characteristics of each sport (soccer, handball, basketball and volleyball), in regard to: body height, bone content of body, fat content of body.

On the graph, the abscissa (horizontal coordinate) is body height, and the ordinate (vertical coordinate) is the bone content of body. It is possible to notice that in relation to the body height, soccer (1) has the least value and the highest value has volleyball (4). Compared to the bone content of body, volleyball (4) has the least value and handball has the highest value is handball (2).

On the graph, the abscissa (horizontal coordinate) is body height, and the ordinate (vertical coordinate) is fat content of body. It is possible to notice that in relation to the body height, soccer (1) has the least value, and the highest value has volleyball (4) Compared to the fat content of body, soccer (1) has the least value and the highest value has handball (2).

On the graph, the abscissa (horizontal coordinate is bone content of body, and the ordinate (vertical coordinate) is fat content of body. It is possible to notice that in relation to the bone content of body, volleyball (4) has the least value, and the highest value has handball (2). Compared to the fat content of body, soccer (1) has the least value, and the highest value has handball (2). 


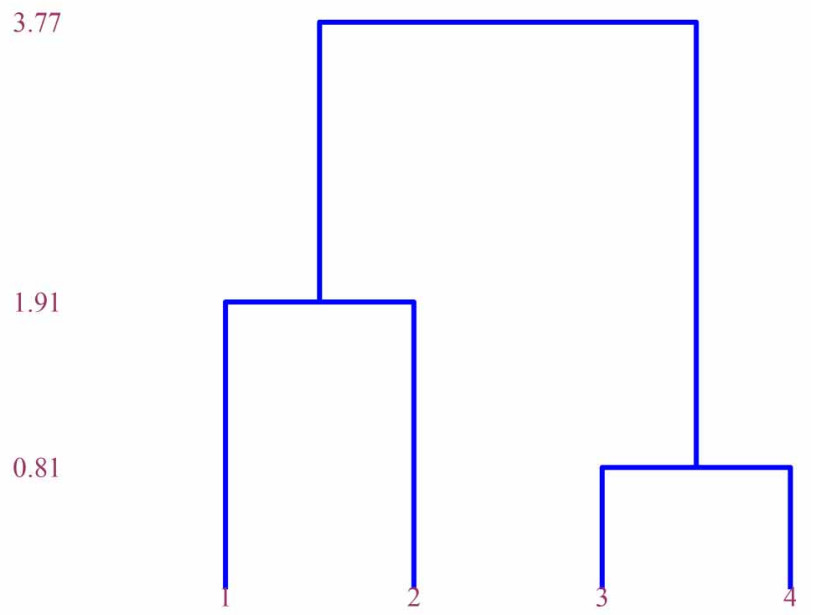

Fig. 1. Dendrogram hierarchical clustering Legend: soccer (1), handball (2), basketball (3), volleyball (4).

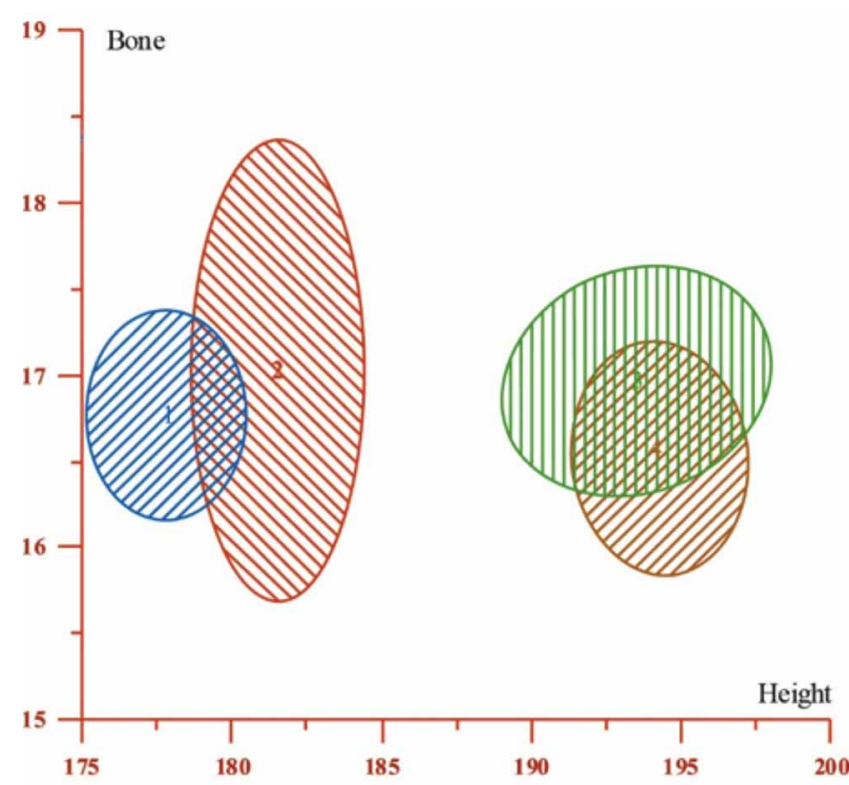

Fig. 2. Ellipses (confidence intervals), of the players of various sports of body height and bone content of body. Legend: soccer (1), handball (2), basketball (3), volleyball (4), height, bone content of body.

\section{DISCUSSION}

The results support the previous research that indicates a strong difference in body height between handball, handball, basketball and volleyball (Jeukendrup \& Gleeson; Ramos-Campo et al.). So the selection criteria,

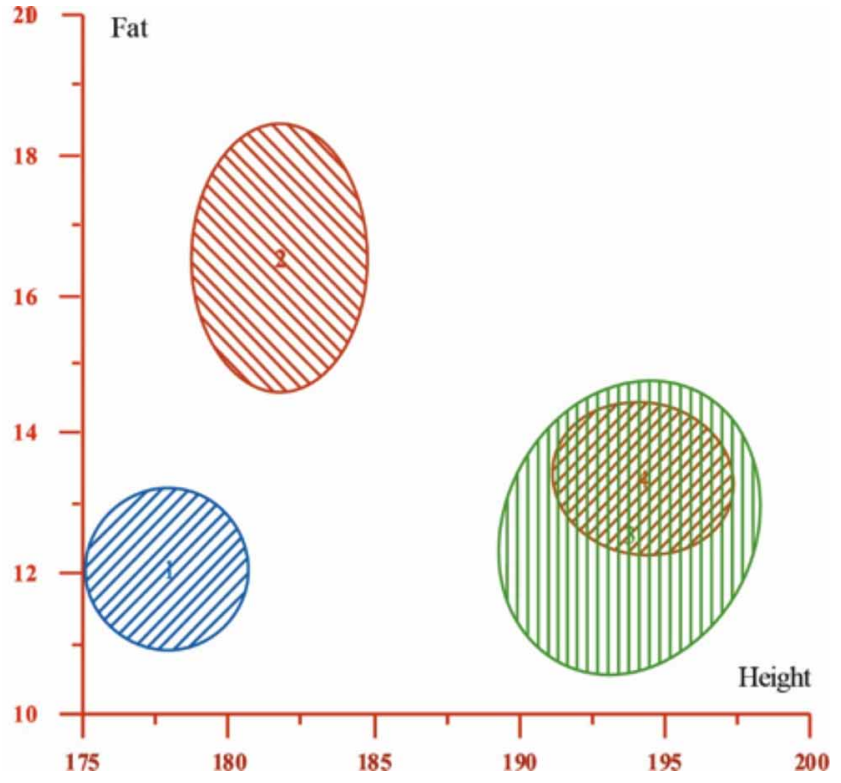

Fig. 3. Ellipses (confidence intervals), of the players of various sports of body height and fat content of body. Legend: soccer (1), handball (2), basketball (3), volleyball (4), height, fat content of body.

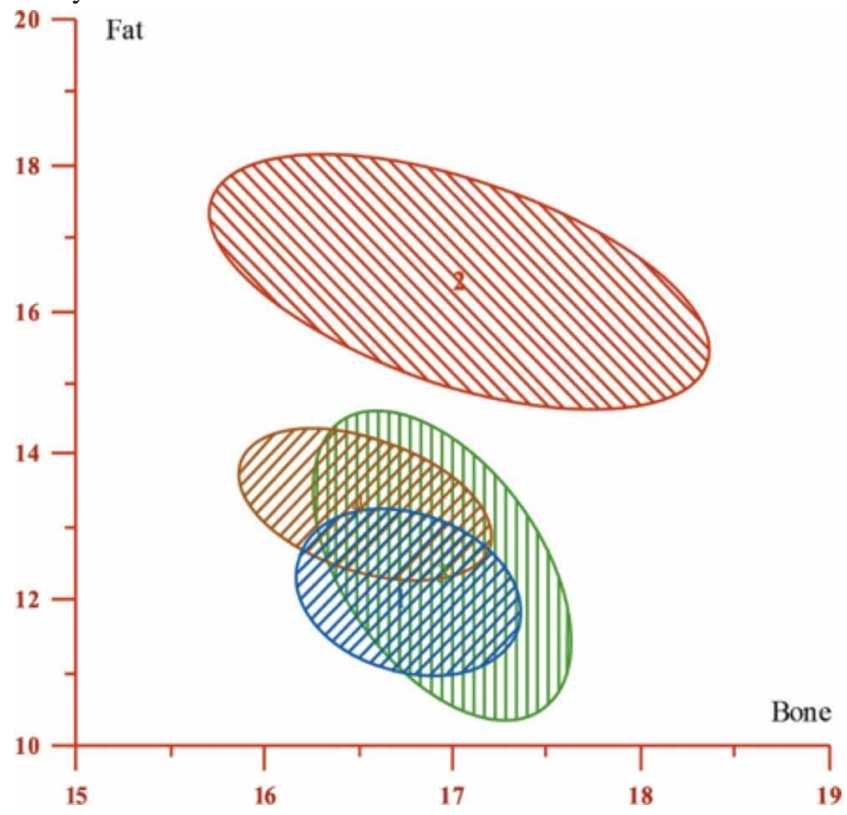

Fig. 4. Ellipses (confidence intervals), for players of various sports of bone content and fat content of body. Legend: soccer (1), handball (2), basketball (3), volleyball (4), bone content of body, fat content of body.

the different types of games and the rules of the game between these sports can explain the observed difference. Additionally, the results confirm that soccer, basketball, and volleyball selection for this study was well done. We will be 
easily convinced if we take a look at the official statistical data who reveal that the average height of all the participants in the FIFA U-17 World Soccer Championship India 2017 was 176.01 centimeters, average height of 2016 FIBA U17 World Basketball Championship players in played in Zaragoza in Spain, was $195.56 \mathrm{~cm}$, the average height of all participants in the CEV U17 Volleyball European Championship 2017 in Turkey was $189 \mathrm{~cm}$. This also proves that the players from Serbian soccer, handball and basketball junior premier league are tall enough and they do not lag behind the top players in the world. On the other hand height of handball players obtained by this study raises doubts that the selection process has been performed correctly, especially due to the fact that official statistics show that players from Serbian national league are shorter than the most successful teams from IHF Men's Youth World Championship played in Russia 2015. For example, the average height of the national handball team of France, which won the championship, was 191.8 centimeters, while Korea ranked 13th with a mean of 183.4 centimeters, Poland ranked 19th with a mean of 190.1 centimeters and Japan ranked 20th with an average of 181.7 centimeters. The teams from Africa and Asia are comparably shorter than the majority of European Teams (Taborsky, 2007) and players from the Serbian national league have similar heights, however, none of these teams showed good results. Serbian players have not had winning scores for years, which further raises doubts with regard to an appropriate selection process. This insight may suggest that coaches from Serbia follow the recent selection process methods and be more careful during the talent identification as they have a very high population in general (Popovic et al., 2013). It is well known that the density of very high subjects appears to be the characteristic of the people from this area (Western Balkans), since high percentages of people from the general population were measured at 190 centimeters or more in body height (Bjelica et al., 2012; Masanovic, 2017).

The following most discriminative three components, when different sports in comparison, are bone, fat and muscle content of body. Previous research indicates that people who do sport and force their bones to support impacts and load have better bone health than sedentary people (Bedogni et al., 2002). Zouch et al. (2008) conclude that bone mass is higher in those bones that support the impacts and changes of directions, as it happens in sports such as handball, basketball and soccer, which affirms the results of this research which confirm that bone content of volleyball players is slightly lower than of the players of other three mentioned sports. Ubago-Guisado et al. (2015) also describe soccer, basketball and handball as the sports of high impact, which show higher values compared with other. However, it is interesting that the percent of fat content in the body of handball players is insignificantly higher than the percent of fat content in the body of subjects from other group. These differences are based upon different circumstances in each sport. Handball trainings contain anaerobic activity, because this game requires higher intensity body-contact and wellcoordinated activities, constant shooting under the pressure, against hard defense players (Buchheit et al., 2009). Consequently, it is now well-established that elite handball players should have high stature and body mass (Nikolaidis \& Ingebrigtsen, 2013). It is very important to remember that athletes in elite team need a determined body fat percentage to perform well enough and achieve their full playing potential. Also, the organism of people who have too little fat tissue becomes submissive to certain risks. An important decline of fat levels can lead to complications and contraindications. Adipose tissue is a complex, essential, and highly active metabolic and endocrine organ (Kershaw \& Flier, 2004) who communicates with the central nervous system (Costa et al., 2011). In addition to energy storage, also regulate energy metabolism via secreting adipokines into the circulation (Ozenoglu et al., 2008). Adipokines is bioactive peptides, which act at both the local and systemic level. For us, the most interesting might be Leptin, Adiponectin and Interleukin 6. Leptin plays a role in the regulation of energy consumption, in proliferation of many normal and neoplastic tissues, in hematopoiesis and reproduction (Milosevic et al., 2015). Leptin normalizes suppressed thyroid hormoneptin, has direct effects via peripheral leptin receptors in the ovary, testis, prostate, and placenta. Also leptin is included in regulation of immune function, angiogenesis, stimulates endothelial cell growth, accelerates wound healing, and play important role in bone development (Kershaw \& Flier). Adiponectin has antidiabetic, anti-inflammatory and anti-atherogenic properties (Silva et al., 2016). Interleukin 6 acts as a proinflammatory and antinflammatory cytokine (Marginean et al., 2013; Safil et al., 2015), helps regulate responses to the trauma, especially burns and other damaged tissues that lead to inflammation, and it is necessary for resistance against Streptococcus pneumoniae. His lack would weaken the organism (Fischer, 2006). Through this interactive network, adipose tissue is integrally involved in coordinating a variety of biological processes (Fusaru et al., 2012). Thus, both excess and deficiency of adipose tissue have harmful metabolic consequences and represent significant medical and socioeconomic burdens in the world today. Lastly, the author found that the basketball players have significantly higher muscle content than the soccer players, which is seen in the table overview. These results may be explained by more demands to increase the muscle content of the body in basketball players. It is also interesting to mention that basketball players have to use both upper and lower extremities, while soccer players use only lower extremities, possibly 
an additional reason why the authors reached these results. Regardless of lower values for soccer players, we should not doubt the selection process; it also corresponds to the fat content values we find in the established literature (Jeukendrup \& Gleeson). Handball players and volleyball players are ranked in the middle, between these two groups and have no significant difference compared to soccer and basketball players.

The new information that was generated in this study will aid defining a more precise top soccer, handball, basketball and volleyball player profile. The possibility of having a look at the similarities, differences and distances between certain parameters, is a considerable contribution of this research to the broader knowledge base. Also value for the coaches' evaluation represents knowledge about the current distance soccer, handball, basketball and volleyball players from Serbia and the world top teams, as well as knowing about the ways the coaches in handball should take, in order to get closer to the world leading teams.

\section{ACKNOWLEDGEMENTS}

The researchers are grateful to Ivan Masanovic from the Design Studio Ideator from Novi Sad for his contribution to design of the figures in this manuscript.

MASANOVIC, B. Estudio comparativo de las características morfológicas y la composición corporal entre diferentes jugadores de equipos de la Liga Nacional Junior de Serbia: fútbol, balonmano, baloncesto y voléibol. Int. J. Morphol., 37(2):612-619, 2019.

RESUMEN: El propósito de este estudio fue definir cada submuestra con precisión, para presentar una visión general de la importancia de las diferencias entre los distintos jugadores, así como para señalar la cercanía y la distancia entre ellos y, finalmente, para determinar la antropología latente. Estas características cuando están en interacción, contribuyen a encontrar diferencias significativas y mejorar la comprensión de las características específicas de cada deporte mencionado. Sesenta y siete hombres se inscribieron en el estudio, divididos en cuatro grupos: 25 jugadores de fútbol, 15 jugadores de balonmano, 13 jugadores de baloncesto y 14 jugadores de voleibol. Se evaluaron las medidas antropométricas de todos los sujetos para calcular las variables de composición corporal, utilizando los procedimientos estandarizados recomendados por la literatura establecida. Los datos se analizaron mediante SPSS y las estadísticas descriptivas se expresaron como una media (DE) para cada variable, mientras que las pruebas ANOVA y LSD Post Hoc se realizaron para detectar los efectos de cada tipo de deporte. Distintas características se han identificado mediante el cálculo del coeficiente de discriminación, determinando los detalles de las submuestras, y su agrupación se demostró al calcular la distancia de Mahalanobis. Los resultados mostraron que se encontró una diferencia significativa en la altura del cuerpo, el peso corporal, el contenido muscular del cuerpo, la grasa corporal, la masa residual, la masa corporal ideal y la masa corporal magra. No se observó una diferencia significativa en el índice de masa corporal y el contenido óseo del cuerpo. Se confirmó que existe una línea claramente definida entre los jugadores en diferentes deportes y es posible determinar las características de los jugadores de cada deporte. Los resultados también indicaron que la menor cantidad de diferencias aparece entre el voleibol y el baloncesto, y que los deportes que más se distinguen son el voleibol y el balonmano. Por lo tanto, estos hallazgos pueden darles a los entrenadores de la región, un perfil más preciso de los jugadores de fútbol, balonmano, baloncesto y voleibol, y sugerir que sigan métodos de selección recientes y considerar con mayor atención la identificación del talento.

PALABRAS CLAVE: Características morfológicas; Composición corporal; Deportes diferentes; Junior.

\section{REFERENCES}

Bankovic, V.; Dopsaj, M.; Terzic, Z. \& Nesic, G. Descriptive body composition profile in female olympic volleyball medalists defined using multichannel bioimpedance measurement: Rio 2016 team case study. Int. J. Morphol., 36(2):699-708, 2018.

Barraza, F.; Yáñez, R.; Tuesta, M.; Núñez, P.; Zamora, Y. \& Rosales, G. Anthropometric profile in Chilean handball players according to playing position. Int. J. Morphol., 33(3):1093-101, 2015.

Bedogni, G.; Mussi, C.; Malavolti, M.; Borghi, A.; Poli, M.; Battistini, N. \& Salvioli, G. Relationship between body composition and bone mineral content in young and elderly women. Ann. Hum. Biol., 29(5):55965, 2002.

Bjelica, D.; Popovic, S.; Kezunovic, M.; Petkovic, J.; Jurak, G. \& Grasgruber, P. Body height and its estimation utilizing arm span measurements in Montenegrin adults. Anthropol. Noteb., 18(2):69-83, 2012.

Buchheit, M.; Lepretre, P. M.; Behaegel, A. L.; Millet, G. P.; Cuvelier, G. $\&$ Ahmaidi, S. Cardiorespiratory responses during running and sportspecific exercises in handball players. J. Sci. Med. Sport, 12(3):399405, 2009.

Costa, S. S.; Blotta, R. M.; Meurer, L. \& Edelweiss, M. I. Adipocyte morphometric evaluation and angiogenesis in the omentum transposed to the breast: a preliminary study. Clinics (São Paulo), 66(2):307-12, 2011.

Fieseler, G.; Hermassi, S.; Hoffmeyer, B.; Schulze, S.; Irlenbusch, L.; Bartels, T.; Delank, K. S.; Laudner, K. G. \& Schwesig, R. Differences in anthropometric characteristics in relation to throwing velocity and competitive level in professional male team handball: a tool for talent profiling. J. Sports Med. Phys. Fitness, 57(7-8):985-92, 2017.

Fischer, C. P. Interleukin-6 in acute exercise and training: what is the biological relevance? Exerc. Immunol. Rev., 12:6-33, 2006.

Fusaru, A. M.; Stanciulescu, C. E.; Surlin, V.; Taisescu, C.; Bold, A.; Pop, O. T.; Banita, I. M.; Craitoiu, S. \& Pisoschi, C. G. Role of innate immune receptors TLR2 and TLR4 as mediators of the inflammatory reaction in human visceral adipose tissue. Rom. J. Morphol. Embryol., 53(3 Suppl.):693-701, 2012.

Jakonic, D. Dinamika promena antropoloskih i fizioloskih parametara $u$ toku kontrolisane redukcije telesne mase kod zena. Master Thesis. Novi Sad, School of Medicine, 1993. 
Jeukendrup, A. E. \& Gleeson, M. Sport Nutrition: An Introduction to Energy Production and Performance. Champaign, Human Kinetics, 2009.

Kershaw, E. E. \& Flier, J. S. Adipose tissue as an endocrine organ. J. Clin. Endocrinol. Metab., 89(6):2548-56, 2004.

Krzykaa, M. \& Leszczynski, P. Asymmetry in body composition in female hockey players. Homo, 66(4):379-86, 2015.

Marginean, C. O.; Man, L.; Pitea, A. M.; Man, A.; Marginean, C. L. \& Cotoi, O. S. The assessment between IL-6 and IL-8 and anthropometric status in malnourished children. Rom. J. Morphol. Embryol., 54(4):9358, 2013.

Masanovic, B. Determination of Body Composition of Athletes. Unpublished Master Thesis. Novi Sad, Faculty of Sport and Physical Education, 2008.

Masanovic, B. Relationship between arm span measurements and body height in Dinaric Alpes population: a systematic review. J. Anthropol. Sport Phys. Educ., 1(1):33-7, 2017.

Massuça, L. \& Fragoso, I. Study of Portuguese handball players of different playing status. A morphological and biosocial perspective. Biol. Sport, 28(1):37-44, 2011.

Matiegka, J. The testing of phisical efficiency. Am. J. Phys. Anthropol., 4(3):223-30, 1921

Milosevic, V.; Vukmirovic, F.; Zindovic, M.; Krstic M.; Milenkovic, S. \& Jancic, S. Interplay between expression of leptin receptors and mucin histochemical aberrations in colorectal adenocarcinoma. Rom. J. Morphol. Embryol., 56(2 Suppl.):709-16, 2015.

Nikolaidis, P. T. \& Ingebrigtsen, J. The relationship between body mass index and physical fitness in adolescent and adult male team handball players. Indian J. Physiol. Pharmacol., 57(4):361-71, 2013.

Nikolaidis, P. T. \& Vassilios Karydis, N. Physique and body composition in soccer players across adolescence. Asian J. Sports Med., 2(2):75-82, 2011.

Ozenoglu, A.; Balci, H.; Ugurlu, S.; Caglar, E.; Uzun, H.; Sarkis, C.; Gunay, C. \& E, E. E. The relationships of leptin, adiponectin levels and paraoxonase activity with metabolic and cardiovascular risk factors in females treated with psychiatric drugs. Clinics (São Paulo), 63(5):65160, 2008.

Popovic, S.; Akpinar, S.; Jaksic, D.; Matic, R. \& Bjelica, D. Comparative study of anthropometric measurement and body composition between elite soccer and basketball players. Int. J. Morphol., 31(2):461-7, 2013.

Popovic, S.; Bjelica, D.; Jaksic, D. \& Hadzic, R. Comparative study of anthropometric measurement and body composition between elite soccer and volleyball players. Int. J. Morphol., 32(1):267-74, 2014.

Ramos-Campo, D. J.; Martínez Sánchez, F.; Esteban García, P.; Rubio Arias, J. A.; Bores Cerezal, A.; Clemente-Suarez, V. J. \& Jiménez Díaz, J. F. Body composition features in different playing position of professional team indoor players: basketball, handball and futsal. Int. J. Morphol., 32(4):1316-24, 2014.

Rexhepi, A. M. \& Brestovci, B. The differences in body volume and skinfold thickness between basketball players and footballers. Int. J. Morphol., 28(4):1068-74, 2010.

Rivera-Sosa, J. M. Anthropometric properties and somatotype of basketball players from different competition level. Int. J. Morphol., 34(1):17988, 2016.

Safil, S. Z.; Batumalaie, K.; Mansor, M.; Chinna, K.; Mohan, S.; Karimian, H.; Qvist, R.; Ashraf, M. A. \& Yan, G. O. Glutamine treatment attenuates hyperglycemia-induced mitochondrial stress and apoptosis in umbilical vein endothelial cells. Clinics (São Paulo), 70(8):569-76, 2015.

Silva, M. G.; Borba, E. F.; Mello, S. B. \& Shinjo, S. K. Serum adipocytokine profile and metabolic syndrome in young adult female dermatomyositis patients. Clinics (São Paulo), 71(12):709-14, 2016.

Singh, S.; Singh, K. \& Singh, M. Anthropometric measurements, body composition and somatotyping of high jumpers. Braz. J. Biomotricity, 4(4):266-71, 2010.

Sporis, G.; Dujic, I.; Trajkovic, N.; Milanovic, Z. \& Madic, D. Relationship between morphological characteristics and match performance in junior soccer players. Int. J. Morphol., 35(1):37-41, 2017.
Strel, J. Correlation of physical characteristics and general endurance: A comparison of 7- to 19-year-old pupils between 1983, 1993 and 2003. Anthropol. Noteb., 12(2):113-28, 2006.

Taborsky, F. The Body Height and Top Team Handball Players. Vienna, EHF Web Periodical, 2007.

Toselli, S.; Brasili, P.; Iuliano, T. \& Spiga, F. Anthropometric variables, lifestyle and sports in school-age children: comparison between the cities of Bologna and Crotone. Homo, 65(6):499-508, 2014.

Ubago-Guisado, E.; Gómez-Cabello, A.; Sánchez-Sánchez, J.; GarcíaUnanue, J. \& Gallardo, L. Influence of different sports on bone mass in growing girls. J. Sports Sci., 33(16):1710-8, 2015.

Vila Suárez, M. H.; Ferragut, C.; Alcaraz, P. E.; Rodríguez Suárez, N. \& Cruz Martínez, M. Características cineantropométricas y la fuerza en jugadores juveniles de balonmano por puestos específicos. Arch. Med. Deporte, 25(125):167-77, 2008.

Vukasevic, V.; Spaic, S. \& Masanovic, B. Comparative study of anthropometric measurement and body composition between the basketball player first and second league in Montenegro. J. Anthropol. Sport Phys. Educ., 2(3):61-5, 2018.

Zouch, M.; Jaffré, C.; Thomas, T.; Frère, D.; Courteix, D.; Vico, L. \& Alexandre, C. Long-term soccer practice increases bone mineral content gain in prepubescent boys. Joint Bone Spine, 75(1):41-9, 2008.

\section{Corresponding author: \\ Bojan Masanovic, PhD \\ University of Montenegro \\ Faculty for Sport and Physical Education \\ Narodne omladine bb \\ 81400 Niksic \\ MONTENEGRO}

E-mail: bojanma@ac.me

Received: 17-08-2018

Accepted: 12-12-2018 